\title{
Selective Michael additions to alkylidenemalonates using thiourea-based bifunctional organocatalysts
}

\author{
Declan P. Gavin and John C. Stephens* \\ Department of Chemistry, National University of Ireland Maynooth, Co. Kildare, Ireland \\ E-mail: john.stephens@nuim.ie
}

\begin{abstract}
Bifunctional thiourea catalysts have been found to be excellent promoters of the challenging Michael addition to alkylidenemalonates giving high yields of up to $99 \%$. Substrate structure was important for enantiodiscrimination, with aryl alkylidenemalonate acceptors furnishing products with $e e$ values of up to $73 \%$.
\end{abstract}

Keywords: Organocatalysis, alkylidenemalonates, $\beta$-diketones, nitromethane, Michael addition, bifunctional thiourea catalysts

\section{Introduction}

The development of simple and efficient asymmetric $\mathrm{C}-\mathrm{C}$ bond forming reactions is a major challenge for the synthetic chemist. ${ }^{1,2}$ In recent times, the organocatalysed Michael addition of carbon-centred nucleophiles to activated olefins has been established as a particularly effective method for the synthesis of enantiopure molecules. ${ }^{3-7}$ Enamine and iminium ion generating organocatalysts have been successfully applied to the asymmetric Michael addition of aldehydes and ketones to a number of electron-deficient olefins, e.g. nitroolefins and $\alpha, \beta$-unsaturated sulfones, ${ }^{8}$ vinyl phosphonates, ${ }^{9}$ alkylidenemalonates ${ }^{10-13}$ and $\alpha, \beta$-unsaturated aldehydes and ketones. ${ }^{14-17}$ Bifunctional organocatalysts, such as those developed by Takemoto, Chen, Soós, Connon and Dixon, have also proven to be effective catalysts in asymmetric Michael additions but tend to be used with highly activated acceptors. ${ }^{18-22}$ There have been considerably fewer publications reporting the use of bifunctional organocatalysts in the asymmetric Michael addition to the challenging alkylidenemalonates. Alkylidenemalonates are particularly difficult acceptors due to their reduced electrophilicity. Mayr's impressive and large study on the nucleophilicy and electrophilicity of many substrates details this reduced electrophilicity when compared with other common Michael acceptors. ${ }^{23-25}$ Our interest in the Michael addition of pronucleophiles with a relatively acidic hydrogen to alkylidenemalonates is due to the potential synthetic utility of the functional group-rich chiral conjugate addition products (Scheme 1). 


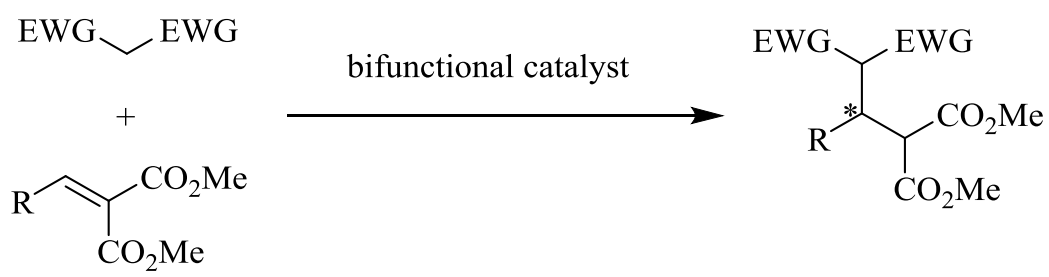

Scheme 1. Michael addition of pronucleophiles to alkylidenemalonates yielding highly functionalized chiral products.

The group of Barbas reported the conjugate addition of ketones to alkylidenemalonates via a pyrrolidine-derived catalyst in $2001 .^{26}$ In fact the majority of reports to date detailing organocatalytic Michael reactions involving alkylidenemalonate acceptors have employed covalent catalysts to promote the reaction. ${ }^{3,27}$ To the best of our knowledge, Zhao and co-workers reported the first H-bonding bifunctional organocatalysed Michael addition to an alkylidenemalonate in 2008. Zhao's report outlines a tandem Michael-Knoevenagel reaction employing aromatic thiols as the pronucleophile in the synthesis of substituted thiochromanes. ${ }^{27}$ There have been only two subsequent publications describing Michael type additions to alkylidenemalonates using $\mathrm{H}$ bonding organocatalysts. In 2012 Yang et al. published an excellent paper discussing the use of novel guanidine derived organocatalysts in the addition of an $\alpha, \beta$-unsaturated $\gamma$-butyrolactam to alkylidenemalonates. ${ }^{28}$ Yang generated an impressively high yielding and highly selective reaction. Recently, Quintavalla and co-workers reported the enantioselective conjugate addition of nitroalkanes to alkylidenemalonates using cinchona derived bifunctional organocatalysts. ${ }^{29}$ It is this publication by Quintavalla that has prompted us to report our initial findings.

In this present study we have employed thiourea-based bifunctional organocatalysts in the enantioselective addition of $\beta$-diketones, malononitrile and nitromethane to alkyl and aryl alkylidenemalonates. Thiourea-based bifunctional organocatalysts have emerged as a viable catalytic design for many asymmetric transformations. ${ }^{30}$ Typically, a thiourea-based bifunctional catalyst consists of a thiourea hydrogen bond donor moiety, for electrophile activation, and a basic amine functionality, for nucleophile activation, Figure $1 .^{18,21}$
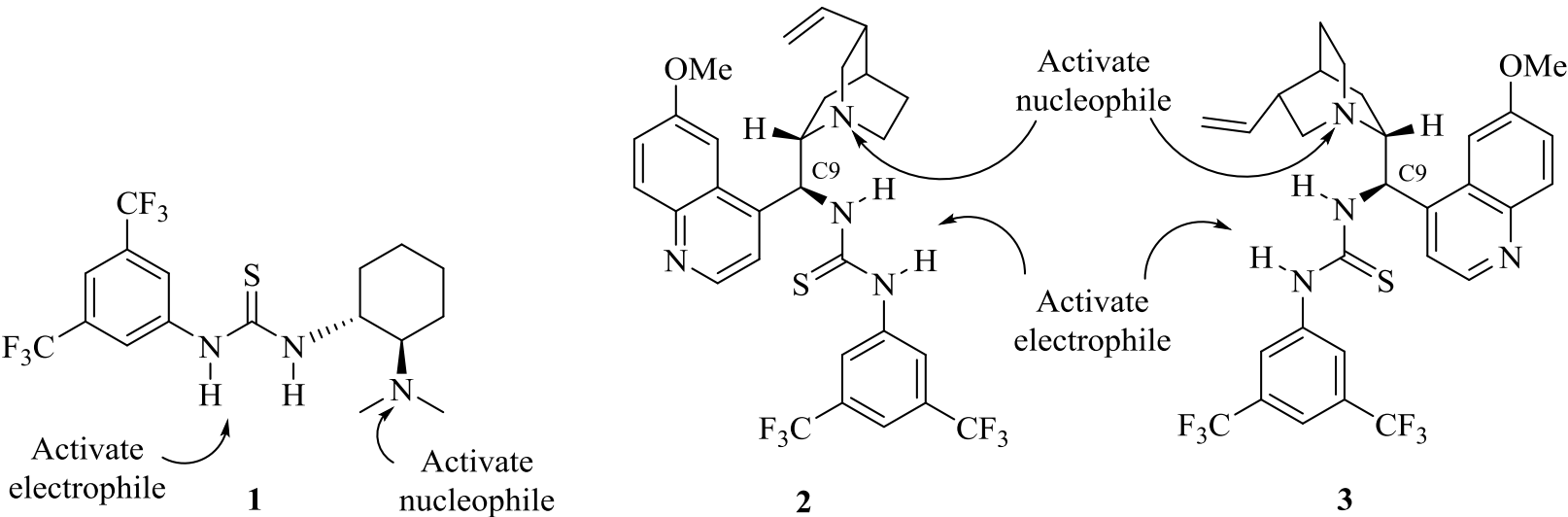

Figure 1. Bifunctional thiourea-based organocatalysts. 
We expected that a thiourea-based amine organocatalyst, due to its dual modes of activation, would offer the best opportunity for the generation of selective Michael type addition to alkylidenemalonates. As a result, we focused our initial catalyst screen on the three thioureabased organocatalysts depicted in Figure 1. Organocatalyst $\mathbf{1}$ has been a highly stereoselective promoter of Michael additions using activated olefins, ${ }^{18}$ as have cinchona alkaloid-derived catalysts $\mathbf{2}$ and $\mathbf{3}^{21}$

\section{Results and Discussion}

The results from the catalyst screen are shown in Table 1 . We employed the addition of 2,4pentanedione to dimethyl ethylidenemalonate as our initial test reaction, entries 1-4, Table 1 . In addition to our work on extended Michael acceptors, ${ }^{31}$ our group is interested in conjugate additions to activated olefins and previous work indicated that the most selective addition of $\beta$ diketones to $\beta$-nitrostyrene using a thiourea-based organocatalyst occurred in toluene. As a result toluene was chosen as the solvent for this work. ${ }^{32}$

Table 1. Michael addition of $\beta$-diketones to dimethyl ethylidenemalonate
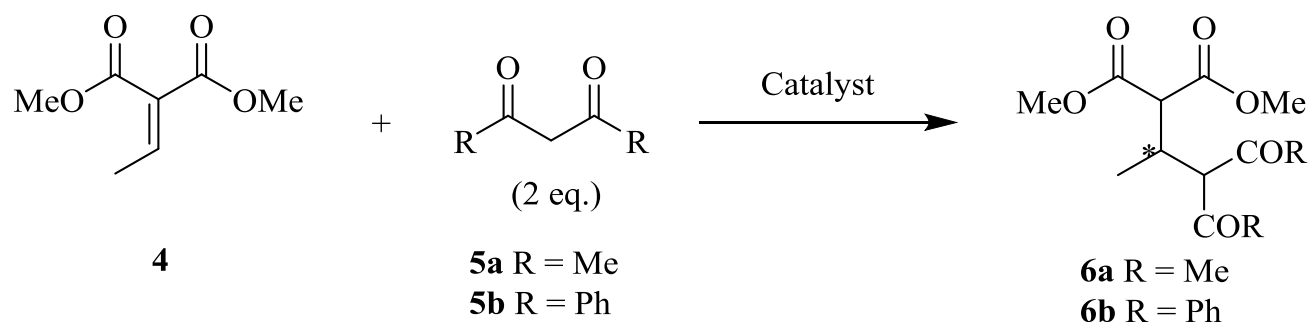

\begin{tabular}{ccccccc}
\hline Entry & $\mathbf{R}$ & Catalyst & $\begin{array}{c}\text { Loading } \\
(\mathbf{m o l} \%)\end{array}$ & $\begin{array}{c}\text { Time } \\
(\mathbf{h})\end{array}$ & $\begin{array}{c}\text { Yield } \\
(\boldsymbol{\%})\end{array}$ & ee $^{\mathbf{a}}(\boldsymbol{\%})$ \\
\hline 1 & $\mathrm{Me}$ & $\mathrm{KO}^{\mathrm{t}} \mathrm{Bu}$ & 5 & 5 & 97 & - \\
2 & $\mathrm{Me}$ & $\mathbf{2}$ & 10 & 12 & 99 & 20 \\
3 & $\mathrm{Me}$ & $\mathbf{3}$ & 10 & 24 & 87 & $(-) 14$ \\
4 & $\mathrm{Me}$ & $\mathbf{1}$ & 10 & 24 & 99 & $(-) 16$ \\
5 & $\mathrm{Ph}$ & $\mathrm{KO}^{\mathrm{t}} \mathrm{Bu}$ & 5 & 5 & 88 & - \\
6 & $\mathrm{Ph}$ & $\mathbf{2}$ & 10 & 24 & 96 & 28 \\
\hline
\end{tabular}

Reaction conditions: $0.028 \mathrm{~mL} \quad(0.2 \mathrm{mmol})$ diethyl ethylidenemalonate, $0.4 \mathrm{mmol}$ pronucleophile, $10 \mathrm{~mol} \%$ catalyst, $0.8 \mathrm{~mL}$ toluene. ${ }^{a}$ Enantiomeric excess determined by chiral HPLC analysis (Chiralpak IC).

All catalysts generated a high yielding reaction, 87-99\%, with modest enantioselectivity. Of the three reactions employing 2,4-pentanedione as the Michael donor, catalyst 2 gave the highest 
selectivity, furnishing the product in $20 \%$ ee. Our group have previously applied the same catalysts in a highly enantioselective addition of $\beta$-diketones to $\beta$-nitrostyrene. ${ }^{32}$ The reduced selectivity with dimethyl ethylidenemalonate, when compared to nitrostyrene, may result from the inferior Lewis basicity of the carbonyl group, in comparison to a nitro group, and hence a weaker catalyst-acceptor interaction. ${ }^{3}$ This weaker interaction with the Lewis acid catalyst may allow the competing and non-stereoselective background reaction to dominate. The Michael addition of 1,3-diphenylpropane-1,3-dione to dimethyl ethylidenemalonate also generated a high yielding reaction, 88-96\%, but again only modest enantioselectivity was observed, entries 5-6, Table 1, although catalyst 2 gave a higher $e e$ value (28\%) with 1,3-diphenylpropane-1,3-dione. The presence of two carbonyl groups allows for convenient H-bonding with the thiourea moiety of the organocatalyst. Figure 2 shows the postulated transition state model, showing activation by the thiourea catalyst of the alkylidenemalonate acceptor and the 1,3-diketone pronucleophile.

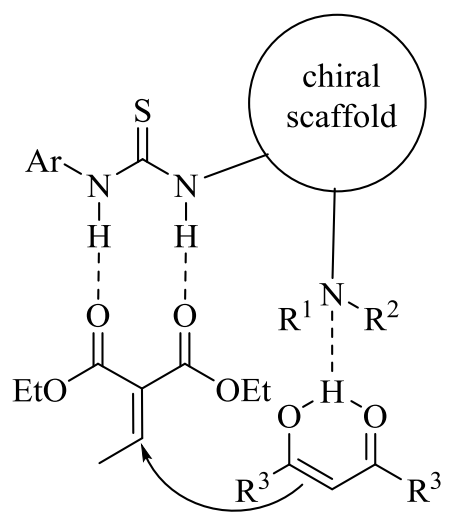

Figure 2. Simultaneous activation of the alkylidenemalonate electrophile and the 1,3-diketone Michael donor.

We also explored the reactivity of the simpler $\alpha, \beta$-unsaturated ester, methyl crotonate 7 , Table 2, reasoning that this substrate would yield useful product synthons in a more atomefficient manner. For this reaction the initial pronucleophile chosen was dimethyl malonate, a prominent Michael donor in conjugate addition reactions. Several base catalysts were screened in the addition of the 1,3-diester to methyl crotonate, Table 2. Triethylamine and DABCO were chosen as the first nitrogen-based achiral promoters of this reaction due to their low cost and ready availability. As no product was detected in these reactions we then tested quinuclidine (the basic unit in our organocatalysts) and the cinchona alkaloid quinine, reasoning that the presence of the H-bonding hydroxyl group in the latter catalyst would activate the Michael acceptor toward attack from the incipient carbanion. Although the amine bases are weak bases, $\mathrm{pKa} \approx 9$ 10 , we wondered if they would promote the conjugate addition via a general base catalyzed mechanism (pKa of dimethyl malonate $\approx 13$ ). However, only reactions employing the stronger inorganic bases generated the desired product. We therefore propose that the reduced electrophilicity of methyl crotonate prevents the amine catalysts from promoting a General Base 
Catalysed reaction and that the Michael addition can only occur under Specific Base Catalysis with the stronger inorganic bases.

Table 2. Michael addition of dimethyl malonate to methyl crotonate

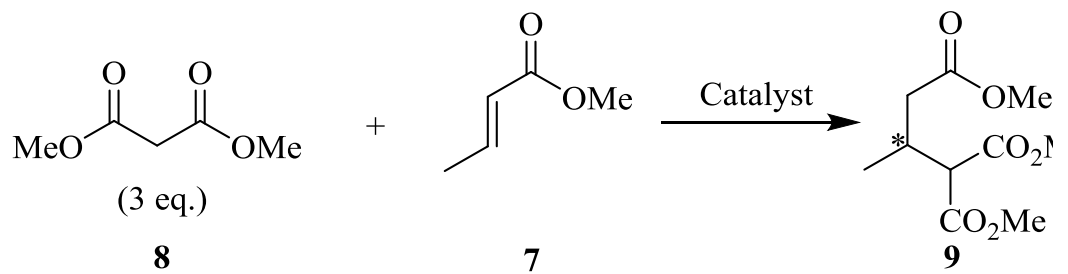

\begin{tabular}{ccccc}
\hline Entry & Catalyst & $\begin{array}{c}\text { Loading } \\
(\mathbf{m o l} \%)\end{array}$ & Time (h) & Yield (\%) \\
\hline 1 & $\mathrm{KO}^{\mathrm{t}} \mathrm{Bu}$ & 5 & 96 & 94 \\
2 & $\mathrm{~K}_{2} \mathrm{CO}_{3}$ & 10 & 96 & 35 \\
3 & $\mathrm{~K}_{2} \mathrm{CO}_{3}$ & 100 & 96 & 88 \\
4 & $\mathrm{NaOMe}$ & 100 & 96 & 65 \\
5 & $\mathrm{Et}_{3} \mathrm{~N}$ & 100 & 96 & $-{ }^{a}$ \\
6 & $\mathrm{DABCO}$ & 100 & 96 & $-{ }^{a}$ \\
7 & Quinuclidine & 100 & 96 & $-{ }^{a}$ \\
8 & Quinine & 100 & 96 & \\
\hline
\end{tabular}

Reaction conditions: $0.015 \mathrm{~mL}(0.1 \mathrm{mmol})$ methyl crotonate, $0.34 \mathrm{~mL}(0.3 \mathrm{mmol})$ dimethyl malonate, catalyst, $2 \mathrm{~mL}$ diethyl ether. ${ }^{a}$ No product detected.

Having established that a second activating ester group on the Michael acceptor is critical for reactivity we extended our substrate scope to non-carbonyl containing pronucleophiles. To do this we employed both nitromethane $\mathbf{1 0 a}$ and malononitrile $\mathbf{1 0 b}$ as pronucleophiles and report their use in the organocatalytic Michael type addition to dimethyl ethylidenemalonate for the first time (Table 3). Mayr's reactivity scales indicate that both nitromethane and malononitrile are excellent nucleophiles, with nucleophilicity values $(\mathrm{N})$ of 20.71 and 19.36, respectively (in DMSO) ${ }^{25}$ We also found this to be the case, with nitromethane generating yields of up to $84 \%$, entry 4, Table 3, and a much improved enantiomeric excess of 48\%, entry 2, Table 3. Malononitrile also proved to be very reactive with yields of $75-89 \%$. Unfortunately, the two product enantiomers could not be separated by chiral HPLC and hence the enantiomeric excess could not be determined. 
Table 3. Michael addition of nitromethane and malononitrile to dimethyl ethylidenemalonate

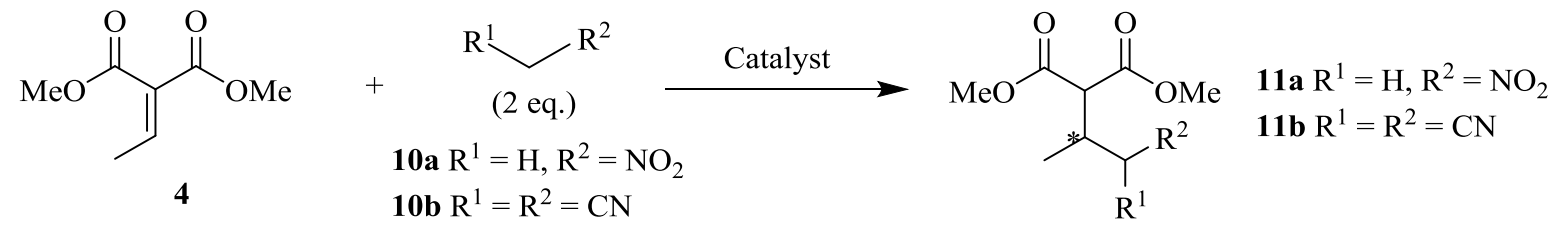

\begin{tabular}{ccccccc}
\hline Entry & Catalyst & Product & $\begin{array}{c}\text { Loading } \\
(\mathbf{m o l} \%)\end{array}$ & Time (h) & $\begin{array}{c}\text { Yield } \\
(\%)\end{array}$ & $\boldsymbol{e e}^{\mathbf{a}(\%)}$ \\
\hline 1 & $\mathrm{KO}^{\mathrm{t}} \mathrm{Bu}$ & $\mathbf{1 1 a}$ & 5 & 96 & 75 & - \\
2 & $\mathbf{2}$ & $\mathbf{1 1 a}$ & 10 & 96 & 73 & 48 \\
3 & $\mathbf{3}$ & $\mathbf{1 1 a}$ & 10 & 96 & $(-) 38$ & 34 \\
4 & $\mathbf{1}$ & $\mathbf{1 1 a}$ & 10 & 96 & $(-) 84$ & 44 \\
5 & $\mathrm{KO}^{\mathrm{t}} \mathrm{Bu}$ & $\mathbf{1 1 b}$ & 5 & 12 & 75 & n.d. \\
6 & $\mathbf{2}$ & $\mathbf{1 1 b}$ & 10 & 4 & 82 & n.d. \\
7 & $\mathbf{3}$ & $\mathbf{1 1 b}$ & 10 & 6 & 79 & n.d. \\
8 & $\mathbf{1}$ & $\mathbf{1 1 b}$ & 10 & 2 & 88 & n.d. \\
\hline
\end{tabular}

Reaction conditions: $0.028 \mathrm{~mL}(0.2 \mathrm{mmol})$ diethyl ethylidenemalonate, $0.4 \mathrm{mmol}$ pronucleophile, $10 \mathrm{~mol} \%$ catalyst, $0.8 \mathrm{~mL}$ toluene. ${ }^{a}$ Enantiomeric excess determined by chiral HPLC analysis (Chiralpak IB, IC).

We also undertook a series of experiments aimed at expanding the scope of this methodology to arylalkylidenemalonates, namely dimethyl benzylidenemalonate 12a and dimethyl 2-(4nitrobenzylidene)malonate $\mathbf{1 2 b}$. The Mayr reactivity scales predict that the addition of 2,4pentanedione (nucleophilicity value, $\mathrm{N}$, of 17.64 in DMSO) ${ }^{24}$ to diethyl benzylidenemalonate (electrophilicity value, E, of -20.55) would be quite slow. The same reactivity scales suggest that adding an electron withdrawing para-nitro group on the aryl ring of the alkyldiene malonate will improve electrophilicity, diethyl 2-(4-nitrobenzylidene)malonate has higher electrophilicity value (E) of $-17.67 .^{23} \mathrm{We}$ observed this improved reactivity in our work as dimethyl benzylidenemalonate 12a proved to be completely unreactive in our hands, entry 1, Table 4 . The nitro-substituted dimethyl 2-(4-nitrobenzylidene)malonate 12b showed an improved reactivity with significant enantioselectivity (Entries 2-5, Table 4). As the acceptor 12a was too poor an electrophile to undergo the organocatalyzed Michael addition we did not explore even less electrophilic substrates containing electron-donating substitutions on the aryl moiety. 
Table 4. Michael addition of 2,4-pentanedione to arylalkylidenemalonates<smiles>[X]C(=O)C(=Cc1ccc([X])cc1)C(=O)OC</smiles>

12a $\mathrm{X}=\mathrm{H}$

12b $\mathrm{X}=\mathrm{NO}_{2}$

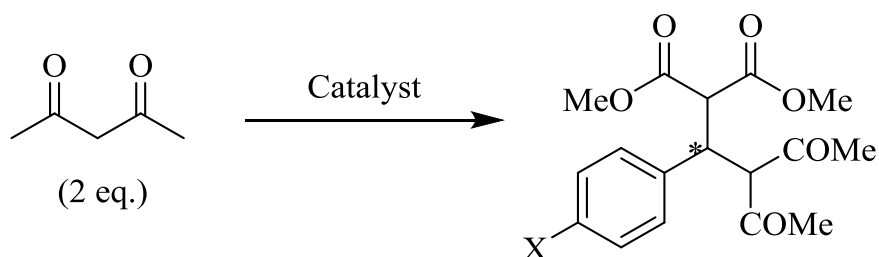

$5 \mathbf{a}$ 13a $\mathrm{X}=\mathrm{H}$

$13 \mathbf{b} \mathrm{X}=\mathrm{NO}_{2}$

\begin{tabular}{ccccccc}
\hline Entry & Catalyst & Product & $\begin{array}{c}\text { Loading } \\
(\mathbf{m o l} \%)\end{array}$ & Time (h) & $\begin{array}{c}\text { Yield } \\
(\boldsymbol{\%})\end{array}$ & $\boldsymbol{e e}^{\mathbf{a}}(\boldsymbol{\%})$ \\
\hline 1 & $\mathbf{2}$ & $\mathbf{1 3 a}$ & 10 & 96 & - & - \\
2 & $\mathrm{KO}^{\mathrm{t}} \mathrm{Bu}$ & $\mathbf{1 3 b}$ & 5 & 96 & 56 & - \\
3 & $\mathbf{2}$ & $\mathbf{1 3 b}$ & 10 & 96 & 28 & 73 \\
4 & $\mathbf{3}$ & $\mathbf{1 3 b}$ & 10 & 96 & 17 & 56 \\
5 & $\mathbf{1}$ & $\mathbf{1 3 b}$ & 10 & 96 & 10 & $(-) 68$ \\
\hline
\end{tabular}

Reaction conditions: $0.1 \mathrm{mmol}$ Michael acceptor, $0.2 \mathrm{~mL}(0.2 \mathrm{mmol})$ acetylacetone, $10 \mathrm{~mol} \%$ catalyst, $0.4 \mathrm{~mL}$ toluene. ${ }^{\mathrm{a}}$ Enantiomeric excess determined by chiral HPLC analysis (Chiralpak IC). ${ }^{\mathrm{b}}$ No product detected.

As can be seen from Table 4, all three catalysts exhibited a greater degree of stereocontrol with arylalkylidenemalonate subsrates compared to the alkyl substituted acceptors. We postulate that the improved selectivity is a consequence of the lower reactivity of dimethyl (4nitrobenzylidene)malonate compared to dimethyl ethylidenemalonate. In the case of the $\beta$-alkylsubstituted acceptor, the $\beta$-carbon is sufficiently electrophilic to allow the non-stereoselective background reaction to occur. It is possible that the aromatic acceptor is too unreactive to allow this background reaction to occur and that it requires an interaction with the thiourea moiety to sufficiently activate it toward nucleophilic attack. The autocatalytic background Michael reaction is unable to proceed due to the lack of reactivity of the uncoordinated (and thus unactivated) electrophile. Thus the presence of the catalyst is essential for reactivity and a more stereoselective reaction ensues.

\section{Conclusions}

In conclusion, we have demonstrated that thiourea-based bifunctional organcatalysts are excellent promoters of conjugate additions to the challenging Michael acceptors, alkylidenemalonates. The structure of the Michael acceptor is very important for enantioselectivity, with the para-nitro-substituted aromatic substrate giving the highest selectivities (up 
to $73 \% e e$ ). The $\beta$-alkyl-substituted acceptor, dimethyl ethylidenemalonate, furnished Michael products in high yields but lower enantiomeric excess. It is likely that this is due to the relatively weak interaction between the catalyst and the carbonyl group of the acceptor, which results in the autocatalytic racemic background reaction prevailing.

\section{Supporting information available}

NMR spectra and HPLC chromatograms are available free of charge via the Internet at http://www.arkat-usa.org.

\section{Experimental Section}

General. Reagents were used as purchased from suppliers, unless otherwise indicated. Solvents were distilled and dried before use. Toluene and anhydrous DMF were used as purchased. Reactions requiring inert conditions were performed in dried glassware under a positive pressure of argon. Reactions were monitored by thin layer chromatography using $\mathrm{SiO}_{2}$ (silica gel 60 F254, Merck, coated aluminum plates), and visualizing by UV light or by aqueous $\mathrm{KMnO}_{4}$ or phosphomolybdic acid solutions. Flash chromatography was carried out on $\mathrm{SiO}_{2}$ (silica gel 60 F254, 230-400 mesh ASTM, Merck). ${ }^{1} \mathrm{H}$ and ${ }^{13} \mathrm{C}$ NMR spectra were recorded with a Bruker Avance 300 NMR spectrometer. Chemical shifts are reported in ppm relative to TMS internal standard $(\delta=0.00)$ in $\mathrm{CDCl}_{3}$ for ${ }^{1} \mathrm{H}$ NMR spectra. For ${ }^{13} \mathrm{C}$ NMR spectra, solvent residual peaks ( $\delta=77.0 \mathrm{ppm}$ for $\mathrm{CDCl}_{3}$ were used as internal reference. Abbreviation of multiplicities is as follows: s (singlet), d (doublet), $\mathrm{t}$ (triplet), $\mathrm{q}$ (quadruplet), m (multiplet), br s (broad singlet). High-resolution mass spectrometric data was recorded with an Agilent Technologies 6410 Time of Flight LC/MS at NUI Maynooth. IR spectra were recorded with Perkin Elmer System 2000 FT-IR instrument. Optical rotations were obtained with a Perkin-Elmer 343 polarimeter $(\lambda=589$ $\mathrm{nm}$ ) using a $0.5 \mathrm{dm}$ cell. Chiral HPLC analysis was performed with a Perkin Elmer Series 200 HPLC. The exact conditions are reported in connection with each analyzed substance. HPLC analyses were performed before crystallization steps to exclude possible additional enantioenrichment. Melting points were recorded with Stuart SMP11 melting point apparatus in open capillary tubes.

Organocatalysts $\mathbf{2}$ and $\mathbf{3}$ were prepared as per literature protocol. ${ }^{32}$

Synthesis of trimethyl 2-methylpropane-1,1,3-tricarboxylate $(9) .{ }^{33}$ To a stirred solution of dimethyl ethylidenemalonate $(0.15 \mathrm{~mL}, 1 \mathrm{mmol})$ and dimethyl malonate $(0.34 \mathrm{~mL}, 3 \mathrm{mmol})$ in diethyl ether $(2 \mathrm{~mL})$ was added base $(5 \mathrm{~mol} \%$ - $100 \mathrm{~mol} \%)$. The reaction was monitored by TLC. Upon consumption of the starting material, the solvent was removed in vacuo and the crude residue was purified by flash chromatography (1:1 hexane : diethyl ether) to afford the conjugate addition product as a colourless oil. 
${ }^{1} \mathrm{H}$ NMR $\left(\mathrm{CDCl}_{3}\right): \delta 3.74\left(\mathrm{~s}, 6 \mathrm{H}, \mathrm{OCH}_{3}\right), 3.68\left(\mathrm{~s}, 3 \mathrm{H}, \mathrm{OCH}_{3}\right), 3.46(\mathrm{~d}, J 7.2 \mathrm{~Hz}, 1 \mathrm{H}$, $\left.\mathrm{CH}\left(\mathrm{COOCH}_{3}\right)_{2}\right), 2.82-2.68\left(\mathrm{~m}, 1 \mathrm{H}, \mathrm{CH}_{3} \mathrm{CH}\right), 2.55\left(\mathrm{dd}, \mathrm{J} 15.8,5.2 \mathrm{~Hz}, 1 \mathrm{H}, \mathrm{CH}_{2}\left(\mathrm{COOCH}_{3}\right)\right), 2.32$ $\left(\mathrm{dd}, J 15.8,6.9 \mathrm{~Hz}, 1 \mathrm{H}, \mathrm{CH}_{2}\left(\mathrm{COOCH}_{3}\right)\right), 1.07\left(\mathrm{~d}, J 6.9 \mathrm{~Hz}, 3 \mathrm{H}, \mathrm{CH}_{3}\right) .{ }^{13} \mathrm{C} \mathrm{NMR}\left(\mathrm{CDCl}_{3}\right)$ : $\delta 172.5(\mathrm{C}=\mathrm{O}), 168.81(\mathrm{C}=\mathrm{O}), 168.83(\mathrm{C}=\mathrm{O}), 55.9\left(\mathrm{CH}\left(\mathrm{COOCH}_{3}\right)_{2}\right), 52.4\left(\mathrm{OCH}_{3}\right), 52.4\left(\mathrm{OCH}_{3}\right)$, $51.6\left(\mathrm{OCH}_{3}\right), 38.4\left(\mathrm{CH}_{2}\left(\mathrm{COOCH}_{3}\right)\right), 30.2\left(\mathrm{CHCH}_{3}\right), 17.6\left(\mathrm{CH}_{3}\right)$.

General procedure for the preparation of Michael adducts $6 \mathrm{a}, 6 \mathrm{~b}, 11 \mathrm{a}, 11 \mathrm{~b}, 13 \mathrm{~b}$. To a stirred solution of the Michael acceptor $(0.2 \mathrm{mmol})$ and pronucleophile $(0.4 \mathrm{mmol})$ in toluene $(0.8 \mathrm{~mL})$ was added the chiral organocatalyst $(0.02 \mathrm{mmol}, 10 \mathrm{~mol} \%)$. The reaction was monitored by TLC. Upon consumption of the $\alpha, \beta$-unsaturated compound (or after $96 \mathrm{~h}$ ) the reaction mixture was concentrated under reduced pressure. The residue was purified by flash chromatography to afford the conjugate addition product.

Dimethyl 2-(3-acetyl-4-oxopentan-2-yl)malonate (6a). Flash column chromatography (1:1 hexane:diethyl ether) afforded $\mathbf{6 a}$ as a colourless liquid. 6a existed as an equilibrium mixture of keto and enol tautomers, with the keto form predominating. Ratio of keto: enol in $\mathrm{CDCl}_{3}$ at 25 ${ }^{\circ} \mathrm{C}$; 93: 7. b.p.: $96-98{ }^{\circ} \mathrm{C} @ 5 \times 10^{-2}$ torr.

${ }^{1} \mathrm{H}$ NMR $\left(\mathrm{CDCl}_{3}\right)$ : Keto: $\delta 3.97\left(\mathrm{~d}, J 9.5 \mathrm{~Hz}, 1 \mathrm{H}, \mathrm{CH}\left(\mathrm{COOCH}_{3}\right)_{2}\right), 3.74\left(\mathrm{~s}, 3 \mathrm{H}, \mathrm{COOCH}_{3}\right), 3.75$ $\left(\mathrm{s}, 3 \mathrm{H}, \mathrm{COOCH}_{3}\right), 3.52\left(\mathrm{~d}, J 5.3 \mathrm{~Hz}, 1 \mathrm{H}, \mathrm{CH}\left(\mathrm{COCH}_{3}\right)_{2}\right), 3.12-3.00\left(\mathrm{~m}, 1 \mathrm{H}, \mathrm{CHCH}_{3}\right), 2.23(\mathrm{~s}, 3 \mathrm{H}$, $\left.\mathrm{COCH}_{3}\right), 2.19\left(\mathrm{~s}, 3 \mathrm{H}, \mathrm{COCH}_{3}\right), 1.03\left(\mathrm{~d}, J 7.1 \mathrm{~Hz}, 3 \mathrm{H}, \mathrm{CH}_{3}\right)$. Enol: $\delta 3.78$ (s, 3H, $\left.\mathrm{COOCH}_{3}\right), 3.63$ $\left(\mathrm{s}, 3 \mathrm{H}, \mathrm{COOCH}_{3}\right), 2.26\left(\mathrm{~s}, 6 \mathrm{H}, \mathrm{COCH}_{3}\right), 1.27\left(\mathrm{~d}, J 7.1 \mathrm{~Hz}, 3 \mathrm{H}, \mathrm{CH}_{3}\right)$

${ }^{13} \mathrm{C} \mathrm{NMR}\left(\mathrm{CDCl}_{3}\right)$ : Keto: $\delta 203.5\left(\left(\mathrm{CH}_{3}\right) C=\mathrm{O}\right), 203.1\left(\left(\mathrm{CH}_{3}\right) C=\mathrm{O}\right), 168.7\left(\left(\mathrm{H}_{3} \mathrm{CO}\right) C=\mathrm{O}\right), 168.5$ $\left(\left(\mathrm{H}_{3} \mathrm{CO}\right) \mathrm{C}=\mathrm{O}\right), 71.3,\left(\mathrm{CH}\left(\mathrm{COOCH}_{3}\right)_{2}\right), 53.1\left(\mathrm{CH}\left(\mathrm{COCH}_{3}\right)_{2}\right), 52.5\left(\mathrm{OCH}_{3}\right), 53.3\left(\mathrm{OCH}_{3}\right), 32.7$ $\left(\mathrm{CHCH}_{3}\right), 30.2\left(\mathrm{COCH}_{3}\right), 29.4\left(\mathrm{COCH}_{3}\right), 14.4\left(\mathrm{CH}_{3}\right)$. Enol: $\delta 196.4\left(\left(\mathrm{CH}_{3}\right)(\mathrm{C}=\mathrm{O}), 168.6\right.$ $\left(\left(\mathrm{H}_{3} \mathrm{CO}\right) \mathrm{C}=\mathrm{O}\right), 168.4\left(\left(\mathrm{H}_{3} \mathrm{CO}\right) \mathrm{C}=\mathrm{O}\right), 111.3(\mathrm{C}=\mathrm{C}) 56.8\left(\mathrm{CH}\left(\mathrm{COOCH}_{3}\right)_{2}\right), 53.4\left(\mathrm{OCH}_{3}\right), 52.7$ $\left(\mathrm{OCH}_{3}\right), 32.0\left(\mathrm{CHCH}_{3}\right), 24.5\left(\mathrm{COCH}_{3}\right), 18.3\left(\mathrm{CH}_{3}\right)$.

HRMS: $m / z$ 281.0987 $\left[\mathrm{C}_{12} \mathrm{H}_{18} \mathrm{O}_{6} \mathrm{Na}(\mathrm{M}+\mathrm{Na})^{+}\right.$requires 281.0996]

HPLC (Chirlapak IC, 2\% isopropyl alcohol in hexane, $1 \mathrm{~mL} / \mathrm{min}, 238 \mathrm{~m}$ ): $\mathrm{t}_{1}=16.4 \mathrm{~min}, \mathrm{t}_{2}=$ $18.1 \mathrm{~min}$.

Dimethyl 2-(3-benzoyl-4-oxo-phenylbutan-2-yl)malonate (6b): Flash column chromatography (2:1 hexane:diethyl ether) afforded $\mathbf{6 b}$ as a colourless liquid. ${ }^{1} \mathrm{H}$ NMR $\left(\mathrm{CDCl}_{3}\right): \delta 8.06-7.99(\mathrm{~m}$, 4H, ArH), 7.55-7.39 (m, 6H, ArH), 5.96 (d, J 7.8 Hz, 1H, CH( $\left.\left.\mathrm{CO}_{2} \mathrm{CH}_{3}\right)_{2}\right), 3.84(\mathrm{~d}, J 6.2 \mathrm{~Hz}, 1 \mathrm{H}$, $\left.\mathrm{CH}(\mathrm{COPh})_{2}\right), 3.68\left(\mathrm{~s}, 6 \mathrm{H}, \mathrm{OCH}_{3}\right), 3.47-3.35\left(\mathrm{~m}, 1 \mathrm{H}, \mathrm{CHCH}_{3}\right), 1.17\left(\mathrm{~d}, J 7.3 \mathrm{~Hz}, 3 \mathrm{H}, \mathrm{CH}_{3}\right) .{ }^{13} \mathrm{C}$ NMR $\quad\left(\mathrm{CDCl}_{3}\right): \quad \delta 195.4 \quad((\mathrm{Ph}) \mathrm{C}=\mathrm{O}), \quad 195.2 \quad((\mathrm{Ph}) \mathrm{C}=\mathrm{O}), \quad 169.2 \quad\left(\left(\mathrm{H}_{3} \mathrm{CO}\right) C=\mathrm{O}\right), \quad 169.0$ $\left(\left(\mathrm{H}_{3} \mathrm{CO}\right) \mathrm{C}=\mathrm{O}\right), 136.9$ (ArC), 136.0 (ArC), 133.8 (ArC), 133.6 (ArC), 128.9 (ArC), 128.7 (ArC), $128.5(\mathrm{ArC}), 57.5\left(\mathrm{CH}\left(\mathrm{COOCH}_{3}\right)_{2}\right), 53.9\left(\mathrm{CH}(\mathrm{COPh})_{2}\right), 52.4,52.3\left(\mathrm{OCH}_{3}\right), 34.2\left(\mathrm{CHCH}_{3}\right), 14.3$ $\left(\mathrm{CH}_{3}\right)$. HRMS: $m / z$ 383.1498 $\left[\mathrm{C}_{22} \mathrm{H}_{23} \mathrm{O}_{6}(\mathrm{M}+\mathrm{H})^{+}\right.$requires 383.1489]. HPLC (Chirlapak IB, 60\% isopropyl alcohol in hexane, $1 \mathrm{~mL} / \mathrm{min}, 238 \mathrm{~m}): \mathrm{t}_{1}=14.7 \mathrm{~min}, \mathrm{t}_{2}=20.5 \mathrm{~min}$.

Dimethyl 2-(1-nitropropan-2-yl)malonate (11a): Flash column chromatography (2:1 hexane : diethyl ether) afforded 11a as a colourless liquid. ${ }^{1} \mathrm{H} \mathrm{NMR}\left(\mathrm{CDCl}_{3}\right): \delta 4.65(\mathrm{dd}, J 12.9,5.1 \mathrm{~Hz}$, $\left.1 \mathrm{H}, \mathrm{NO}_{2} \mathrm{CH}_{2}\right), 4.47\left(\mathrm{dd}, J 12.9,7.7 \mathrm{~Hz}, 1 \mathrm{H}, \mathrm{NO}_{2} \mathrm{CH}_{2}\right), 3.78\left(\mathrm{~s}, 6 \mathrm{H}, \mathrm{COOCH}_{3}\right), 3.55(\mathrm{~d}, J 6.9 \mathrm{~Hz}$, $\left.1 \mathrm{H}, \mathrm{CH}\left(\mathrm{COOCH}_{3}\right)_{2}\right), 3.11-2.98\left(\mathrm{~m}, 1 \mathrm{H}, \mathrm{NO}_{2} \mathrm{CH}_{2} \mathrm{CH}\right), 1.14\left(\mathrm{~d}, J 6.7 \mathrm{~Hz}, 1 \mathrm{H}, \mathrm{CH}_{3}\right)$. 
${ }^{13} \mathrm{C} \mathrm{NMR}\left(\mathrm{CDCl}_{3}\right): \delta 168.1(\mathrm{C}=\mathrm{O}), 168.1(\mathrm{C}=\mathrm{O}), 78.4\left(\mathrm{CH}_{2} \mathrm{NO}_{2}\right), 53.8\left(\mathrm{CH}\left(\mathrm{COOCH}_{3}\right)_{2}\right), 52.81$ $\left(\mathrm{OCH}_{3}\right), 52.82\left(\mathrm{OCH}_{3}\right), 32.0\left(\mathrm{CHCH}_{2} \mathrm{NO}_{2}\right), 15.5\left(\mathrm{CH}_{3}\right)$. HRMS: $m / z 220.0817\left[\mathrm{C}_{8} \mathrm{H}_{14} \mathrm{NO}_{6}(\mathrm{M}+\right.$ $\mathrm{H}^{+}$requires 220.0816]. HPLC (Chirlapak IC, 20\% isopropyl alcohol in hexane, $1 \mathrm{~mL} / \mathrm{min}, 238$ $\mathrm{m}): \mathrm{t}_{1}=8.4 \mathrm{~min}, \mathrm{t}_{2}=9.6 \mathrm{~min}$.

Dimethyl 2-(1,1-dicyanopropan-2-yl)malonate (11b). Flash column chromatography (1:1 hexane : diethyl ether) afforded $\mathbf{1 1 b}$ as a colourless liquid. ${ }^{1} \mathrm{H} \mathrm{NMR}\left(\mathrm{CDCl}_{3}\right): \delta 4.53(\mathrm{~d}, J 5.0 \mathrm{~Hz}$, $\left.1 \mathrm{H}, \mathrm{CH}(\mathrm{CN})_{2}\right), 3.81\left(\mathrm{~s}, 3 \mathrm{H}, \mathrm{CO}_{2} \mathrm{CH}_{3}\right), 3.80\left(\mathrm{~s}, 3 \mathrm{H}, \mathrm{CO}_{2} \mathrm{CH}_{3}\right), 3.53(\mathrm{~d}, J 8.4 \mathrm{~Hz}, 1 \mathrm{H}$, $\left.\mathrm{CH}\left(\mathrm{CO}_{2} \mathrm{CH}_{3}\right)_{2}\right), 2.95-2.84\left(\mathrm{~m}, 1 \mathrm{H}, \mathrm{CHCH}_{2}(\mathrm{CN})_{2}\right), 1.36\left(\mathrm{~d}, J 6.9 \mathrm{~Hz}, 3 \mathrm{H}, \mathrm{CH}_{3}\right) .{ }^{13} \mathrm{C} \mathrm{NMR}$ $\left(\mathrm{CDCl}_{3}\right): \delta 167.5(\mathrm{C}=\mathrm{O}), 167.2(\mathrm{C}=\mathrm{O}), 111.2(\mathrm{C} \equiv \mathrm{N}), 110.9(\mathrm{C} \equiv \mathrm{N}), 53.4\left(\mathrm{CH}\left(\mathrm{CO}_{2} \mathrm{CH}_{3}\right)_{2}\right), 53.3$ $\left(\mathrm{OCH}_{3}\right), 53.2\left(\mathrm{OCH}_{3}\right), 34.9\left(\mathrm{CHCH}_{2}(\mathrm{CN})_{2}\right), 26.8\left(\mathrm{CH}(\mathrm{CN})_{2}\right), 15.0\left(\mathrm{CH}_{3}\right) . \mathrm{HRMS}: \mathrm{m} / z, 225.088$ $\left[\mathrm{C}_{10} \mathrm{H}_{13} \mathrm{~N}_{2} \mathrm{O}_{4}(\mathrm{M}+\mathrm{H})^{+}\right.$requires 225.087]. HPLC (Chirlapak IB, 10\% isopropyl alcohol in hexane, $1 \mathrm{~mL} / \mathrm{min}, 238 \mathrm{~m}): \mathrm{t}_{1}=12.6 \mathrm{~min}, \mathrm{t}_{2}=13.6 \mathrm{~min}$.

Dimethyl 2-(2-acetyl-1-(4-nitrophenyl)-3-oxobutyl)malonate (13b). Flash column chromatography (1:1 hexane : diethyl ether) afforded $\mathbf{1 1 b}$ as a white solid. ${ }^{1} \mathrm{H}$ NMR $\left(\mathrm{CDCl}_{3}\right): \delta 8.14(\mathrm{~d}, J$ $8.8 \mathrm{~Hz}, 2 \mathrm{H}, \mathrm{ArH}), 7.50$ (d, J $8.8 \mathrm{~Hz}, 2 \mathrm{H}, \mathrm{ArH}), 4.73$ (d, J $\left.10.9 \mathrm{~Hz}, 1 \mathrm{H}, \mathrm{HC}\left(\mathrm{CO}_{2} \mathrm{CH}_{3}\right)_{2}\right), 4.42$ (dd, $J$ 10.9, $6.8 \mathrm{~Hz}, 1 \mathrm{H}, \mathrm{ArCH}), 3.81\left(\mathrm{~d}, J 6.8 \mathrm{~Hz}, 1 \mathrm{H}, \mathrm{HC}\left(\mathrm{COCH}_{3}\right)_{2}\right), 3.66\left(\mathrm{~s}, 3 \mathrm{H}, \mathrm{CO}_{2} \mathrm{CH}_{3}\right), 3.60(\mathrm{~s}$, $\left.3 \mathrm{H}, \mathrm{CO}_{2} \mathrm{CH}_{3}\right), 2.29\left(\mathrm{~s}, 3 \mathrm{H}, \mathrm{COCH}_{3}\right), 1.92\left(\mathrm{~s}, 3 \mathrm{H}, \mathrm{COCH}_{3}\right) .{ }^{3} \mathrm{C} \mathrm{NMR}\left(\mathrm{CDCl}_{3}\right): \delta 201.7$ $\left(\left(\mathrm{CH}_{3}\right) \mathrm{C}=\mathrm{O}\right), 201.4\left(\left(\mathrm{CH}_{3}\right) \mathrm{C}=\mathrm{O}\right), 167.9\left(\left(\mathrm{CH}_{3} \mathrm{O}\right) \mathrm{C}=\mathrm{O}\right), 167.7\left(\left(\mathrm{CH}_{3} \mathrm{O}\right) \mathrm{C}=\mathrm{O}\right), 147.4(\mathrm{ArC}), 145.2$ (ArC), 130.4 (ArC), $123.7(\mathrm{ArC}), 71.3\left(\mathrm{HC}\left(\mathrm{CO}_{2} \mathrm{CH}_{3}\right)_{2}\right), 54.6\left(\mathrm{HC}\left(\mathrm{COCH}_{3}\right)_{2}\right), 52.9\left(\mathrm{COOCH}_{3}\right)$, $52.7\left(\mathrm{COOCH}_{3}\right), 43.4(\mathrm{ArC}), 30.4\left(\mathrm{COCH}_{3}\right), 29.5\left(\mathrm{COCH}_{3}\right) \cdot \mathrm{MS}: \mathrm{m} / z 366.1183\left[\mathrm{C}_{17} \mathrm{H}_{20} \mathrm{NO}_{8}(\mathrm{M}+\right.$ $\mathrm{H})^{+}$requires 366.1183$]$

HPLC (Chirlapak IC, 30\% isopropyl alcohol in hexane, $1 \mathrm{~mL} / \mathrm{min}, 238 \mathrm{~m}$ ): $\mathrm{t}_{1}=13.3 \mathrm{~min}, \mathrm{t}_{2}=$ $14.9 \mathrm{~min}$.

\section{Acknowledgements}

We thank NUI Maynooth and the Higher Education Authority for funding. We also thank Orla Fenelon and Barbara Woods for MS analysis.

\section{References}

1. Woodward, S., Chem. Soc. Rev. 2000, 29, 393. http://dx.doi.org/10.1039/b002690p

2. Sibi, M. P.; Manyem, S. Tetrahedron 2000, 56, 8033. http://dx.doi.org/10.1016/S0040-4020(00)00618-9

3. Vicario, J. L.; Badia, D.; Carillo, L.; Reyes, E. Organocatalytic Enantioselective Conjugate Addition Reactions, The Royal Society of Chemistry, Cambridge, 2010. 
4. Pellissier, H. Recent Developments in Asymmetric Organocatalysis, The Royal Society of Chemistry, Cambridge, 2010.

5. Tsogoeva, S. B. Eur. J. Org. Chem. 2007, 1701. http://dx.doi.org/10.1002/ejoc.200600653

6. Lu, L.-Q.; An, X.-L.; Chen, J.-R.; Xiao, W.-J. Synlett 2012, 490.

7. Almaşi, D.; Alonso, D. A.; Nájera, C. Tetrahedron: Asymmetry 2007, 18, 299. http://dx.doi.org/10.1016/j.tetasy.2007.01.023

8. Sulzer-Mossé, S.; Alexakis, A. Chem. Commun. 2007, 3123. http://dx.doi.org/10.1039/b701216k PMid:17653365

9. Sulzer-Mossé, S.; Tissot, M.; Alexakis, A. Org. Lett. 2007, 9, 3123. http://dx.doi.org/10.1021/ol7015498 PMid:17715930

10. Cao, C.-L.; Sun, X.-L.; Zhou, J.-L.; Tang, Y. J. Org. Chem. 2007, 72, 4073. http://dx.doi.org/10.1021/jo070070p PMid:17474778

11. Zhao, G.-L.; Vesely, J.; Sun, J.; Christensen, K. E.; Bonneau, C.; Córdova, A. Adv. Synth. Catal. 2008, 350, 657.

http://dx.doi.org/10.1002/adsc. 200700570

12. Wen, L.; Shen, Q.; Lu, L. Org. Lett. 2010, 12, 4655. http://dx.doi.org/10.1021/ol101894h PMid:20849077

13. Magar, D. R.; Chang, C.; Ting, Y.-F.; Chen, K. Eur. J. Org. Chem. 2010, 2062. http://dx.doi.org/10.1002/ejoc.201000072

14. Vakulya, B.; Varga, S.; Csámpai, A.; Soós, T. Org. Lett. 2005, 7, 1967. http://dx.doi.org/10.1021/o1050431s PMid:15876031

15. Wang, J.; Li, W.; Zu, L.; Wei, J.; Xie, H.; Duan, W.; Wang, W. J. Am. Chem. Soc. 2006, 128, 12652. http://dx.doi.org/10.1021/ja065187u PMid:17002351

16. Wu, F.; Hong, R.; Khan, J.; Liu, X.; Deng, L. Angew. Chem. Int. Ed. 2006, 45, 4301. http://dx.doi.org/10.1002/anie.200600867 PMid:16739143

17. Bella, M.; Jørgensen, K. A. J. Am. Chem. Soc. 2004, 126, 5672. http://dx.doi.org/10.1021/ja0493594 PMid:15125652

18. Okino, T.; Hoashi, Y.; Takemoto, Y. J. Am. Chem. Soc. 2003, 125, 12672 http://dx.doi.org/10.1021/ja036972z PMid:14558791

19. Li, B.-J.; Jiang, L.; Liu, M.; Chen, Y.-C.; Ding, L.-S.; Wu, Y. Synlett 2005, 603.

20. Vakulya, B.; Varga, S.; Soós, T. J. Org. Chem. 2008, 73, 3475. http://dx.doi.org/10.1021/jo702692a PMid:18376862

21. McCooey, S. H.; Connon, S. J. Angew. Chem. 2005, 117, 6525. http://dx.doi.org/10.1002/ange.200501721

22. Ye, J.; Dixon, D. J.; Hynes, P. S. Chem. Commun. 2005, 4481. http://dx.doi.org/10.1039/b508833j PMid:16136258

23. Mayr, H; Kempf, B; Ofial, A. R. Acc. Chem. Res. 2002, 36, 66. http://dx.doi.org/10.1021/ar020094c PMid:12534306 
24. Zenz, I; Mayr, H. J. Org. Chem. 2011, 76, 9370.

http://dx.doi.org/10.1021/jo201678u PMid:21978126

25. Kaumanns, O.; Lucius, R.; Mayr, H. Chem. Eur. J. 2008, 14, 9675. http://dx.doi.org/10.1002/chem.200801277 PMid:18792024

26. Betancort, J. M.; Sakthivel, K.; Rajeswari, T.; Barbas, C. F. Tetrahedron Lett. 2001, 42, 4441. http://dx.doi.org/10.1016/S0040-4039(01)00793-6

27. Dodda, R.; Mandal, T.; Zhao, C.-G. Tetrahedron Lett. 2008, 49, 1899. http://dx.doi.org/10.1016/j.tetlet.2008.01.113 PMid:19295905 PMCid:2350192

28. Yang, Y.; Dong, S.; Liu, X.; Lin, L.; Feng, X. Chem. Commun. 2012, 48, 5040. http://dx.doi.org/10.1039/c2cc31470c PMid:22499216

29. Chiarucci, M.; Lombardo, M.; Trombini, C.; Quintavalla, A. Adv. Synth. Catal. 2012, 354, 364.

http://dx.doi.org/10.1002/adsc.201100732

30. Connon, S. J. Chem. Eur. J. 2006, 12, 5418. http://dx.doi.org/10.1002/chem.200501076 PMid:16514689

31. Murphy, J. J.; Quintard, A.; McArdle, P.; Alexakis, A.; Stephens, J. C. Angew. Chem. Int. Ed. 2011, 50, 5095. http://dx.doi.org/10.1002/anie.201100804 PMid:21538747

32. Gavin, D. P.; Stephens, J. C. Arkivoc 2011, (ix), 407. http://dx.doi.org/10.3998/ark.5550190.0012.930

33. Alvarez, E.; Cuvigny, T.; Hervé du Penhoat, C.; Julia, M. Tetrahedron 1988, 44, 119. http://dx.doi.org/10.1016/S0040-4020(01)85099-7 